\title{
PERTUMBUHAN DAN PEMATANGAN GONAD IKAN GIRU Amphiprion clarkii YANG DIBERI PAKAN MENGANDUNG HORMON OODEV
}

\section{GROWTH AND GONADAL MATURATION IN CLOWNFISH Amphiprion clarkii FED WITH FOOD CONTAINING OODEV}

\author{
Aprelia Martina Tomasoa ${ }^{1}$, Deidy Azhari ${ }^{1}$, Walter Balansa ${ }^{1}$ \\ ${ }^{1}$ Program Studi Teknologi Budidaya Ikan, \\ Politeknik Negeri Nusa Utara, Tahuna \\ Korespondensi : apriltomasoa@gmail.com
}

\begin{abstract}
Somatic growth and gonadal maturation play a crucial role in fish farming. To obtain high quality fries, broodstocks should be at the maturity stage of gonadal development and have precise body size. Widely used in fish farming, Oodev induces gonadal maturation as it contains pregnant mare serum gonadotropin and anti-dopamine that together actively affect gonadal maturation. Despite its popularity in fish farming, the effect of this hormone on the somatic growth and gonadal maturation of Amphiprion clarkii is not well understood. This research aims to determine the effect of Oodev mixed in fish feed on somatic growth and gonadal maturation of clownfish $A$. clarkii. The fish were treated for 30 days with three different levels of Oodev with a dose of $0 \mathrm{~mL} / \mathrm{kg}, 0,5 \mathrm{~mL} / \mathrm{kg}$, and $1 \mathrm{~mL} / \mathrm{kg}$ added in fish feed, designed in triplicate for each treatment. The results showed that treatment with $1 \mathrm{~mL} / \mathrm{kg}$ Oodev had a more significant effect than control, increasing both length $(0,9 \mathrm{~cm}$ in male and 0,7 in female) and weight $(1,32$ gram in male and 3,05 gram in female) of the treated fish. Similarly, the same dose had higher Gonadosomatic Index score than control with GSI of $0,47 \%$ (male) and $0,58 \%$ (female) higher than control respectively. In conclusion, the treatment with 1 $\mathrm{mL} / \mathrm{kg}$ Oodev formulated ini fish feed showed the best effect on both somatic growth and GSI of $A$. clarkii.
\end{abstract}

Keyword: Amphiprion clarkii, growth, maturation, Oodev

\begin{abstract}
ABSTRAK
Pertumbuhan dan pematangan gonad memainkan peranan penting dalam budidaya ikan. Untuk memperoleh benih yang berkualitas, induk harus benar-benar matang gonad dan memiliki ukuran tubuh yang sesuai. Umum digunakan dalam kegiatan budidaya ikan, hormon Oodev dapat merangsang pematangan gonad karena hormon Oodev ini mengandung pregnant mare serum gonadotropin dan antidopamin yang sama-sama berperan dalam pematangan gonad. Sekalipun hormon ini begitu populer di bidang budidaya ikan, pengaruh hormon ini terhadap pertumbuhan tubuh dan pematangan gonad terhadap ikan giru (Amphiprion clarkii) belum banyak diketahui. Penelitian ini bertujuan untuk mengevaluasi pengaruh dan menentukan dosis pemberian hormon Oodev dalam pakan terhadap pertumbuhan panjang dan bobot serta pematangan gonad ikan giru. Ikan giru diberi perlakuan dengan tiga dosis hormon Oodev berbeda yaitu $0 \mathrm{~mL} /$ $\mathrm{kg}, 0,5 \mathrm{~mL} / \mathrm{kg}$, dan $1 \mathrm{~mL} / \mathrm{kg}$ dengan tiga pengulangan selama 30 hari pemeliharaan. Hasil menunjukkan dosis $1 \mathrm{~mL} /$ $\mathrm{kg}$ meningkatkan pertumbuhan panjang tubuh pada jantan $(0,9 \mathrm{~cm})$ maupun betina $(0,7 \mathrm{~cm})$ dan pertumbuhan bobot pada jantan (1,32 gram) maupun betina (3,05 gram) lebih tinggi dengan kontrol. Sejalan dengan pertumbuhan panjang dan bobot, dosis $1 \mathrm{~mL} / \mathrm{kg}$ meningkatkan nilai gonadosomatic index jantan dan betina yaitu $0,47 \%$ dan $0,58 \%$ lebih tinggi dengan kontrol. Dari hasil yang diperoleh dapat ditarik kesimpulan bahwa hormon Oodev dengan dosis $1 \mathrm{~mL} / \mathrm{kg}$ dapat meningkatkan pertumbuhan dan nilai GSI $A$. clarkii.
\end{abstract}

Kata kunci: Amphiprion clarkii, Oodev, pematangan gonad, pertumbuhan 


\section{PENDAHULUAN}

Perkembangan budidaya ikan hias air laut semakin berkembang dengan meningkatnya permintaan di pasaran. Salah satu ikan hias yang sekarang banyak dikembangkan adalah ikan giru (Amphiprion clarkii) sering juga disebut ikan nemo atau ikan badut. Berdasarkan data statistik KKP (2017), volume produksi ikan hias nasional mengalami kenaikkan rata-rata sebesar $16,53 \%$ dan tingkat ekspor berbagai jenis ikan hias tumbuh sebesar 13,82\% per tahun, salah satunya ikan giru yang merupakan komoditi ikan hias air laut mendapat perhatian besar (Pitaloka 2007).

Ikan giru terdistribusi hampir di seluruh perairan Barat Indo-Pasifik, yaitu di Teluk Persia hingga Australia bagian barat, Kepulauan Indo-Australia, Kepulauan Melanesia bagian barat, Mikronesia, Taiwan, Jepang bagian selatan dan Kepulauan Ryukyu (Rondonuwu et al. 2013). Hasil penelitian Sembiring et al. (2013), menjelaskan bahwa iklim tropis Indonesia cocok untuk budidaya berbagai jenis ikan hias dan memungkinkan dapat berproduksi sepanjang tahun sehingga pengembangan budidaya ikan hias di Indonesia memiliki prospek yang baik. (Rondonuwu et al. 2013).

Pirarat et al. (2011) melaporkan populasi ikan giru mengalami penurunan dengan cepat dan hampir mencapai titik kritis karena eksploitasi di alam yang terjadi secara terus menerus. Oleh karena itu, tingginya permintaan ikan giru di pasaran harus diimbangi dengan kegiatan budidaya. Dalam budidaya ikan giru, proses pembenihan telah dilakukan sejak tahun 2010 namun permasalahan pengembangan budidaya ikan ini sulit untuk memperoleh benih yang berkualitas dengan memenuhi syarat ekspor (Sembiring et al. 2013).

$$
\text { Rekayasa hormonal untuk }
$$

mempercepat pematangan gonad ikan giru dapat menyediakan benih yang berkelanjutan. Hormon Oodev mengandung pregnant mare serum gonadotropin dan antidopamin yang bekerja untuk mempercepat pematangan gonad pada vetebrata termasuk ikan giru. Tomasoa et al. (2015) menyatakan hormon perangsang folikel dan lutien yang terkandung dalam pregnant mare serum gonadotropin merupakan hormon gonadotropin yang dihasilkan oleh adhenohipofisis bertugas untuk merangsang pertumbuhan dan aktivitas gonad ikan. Menurut Chen dan
Fernald (2008), antidopamin adalah bahan kimia yang dapat bekerja menghentikan kinerja dopamin. Dopamin merupakan neurotransmitter yang berperan dalam menghambat pematangan gonad. Aktivitas dopamin yang terhambat menstimulasi sintesis dan pelepasan hormon lutein yang diinisiasi oleh Gonadotropin-Releasing Hormone (GnRH) di kelenjar pituitari (Rousseau et al. 2009). Selanjutnya produksi hormon folikel dan lutein akan masuk ke organ target gonad melalui pembuluh darah.

Penelitian penggunaan hormon Oodev untuk pematangan gonad ikan budidaya konsumsi telah banyak dilakukan diantaranya ikan Tor soro (Wahyuningsih 2012), ikan gabus (Hutagalung et al. 2015), ikan biawan (Farida et al. 2018). Untuk ikan budidaya hias gurami coklat (Nur et al. 2017) dan khususnya bagi ikan giru penggunaan hormon Oodev untuk induksi pematangan gonad sudah dilakukan oleh Manik (2016) pada ikan giru (A. percula). Dari urairanuraian di atas maka tujuan penelitian ini adalah untuk mengevaluasi pengaruh dan menentukan dosis terbaik pemberian hormon Oodev terhadap pertumbuhan dan pematangan gonad ikan giru (A. clarkiı).

\section{METODE PENELITIAN}

\section{Persiapan wadah dan induk}

Wadah pemeliharaanyang digunakan berupa akuarium berukuran 50x30x40 $\mathrm{cm}^{3}$. Akuarium dilengkapi instalasi aerasi, top filter, potongan pipa PVC berukuran 4 inc dengan diameter sebesar $5,75 \mathrm{~cm}$ dan diisi air laut dengan ketinggian $25 \mathrm{~cm}$. Induk ikan giru (A. clarkii) menggunakan induk yang ditangkap dari alam di perairan Teluk Tahuna, Kabupaten Kepulauan Sangihe, Sulawesi Utara pada kedalaman 3-10 m dengan bantuan alat snorklling dan scuba. Alat tangkap yang digunakan untuk menangkap induk ikan berupa serokan ikan. Menangkap ikan giru di alam sangat mudah, ikan giru akan banyak pada daerah yang memiliki anemon dan diambil menggunakan serokan ikan. Setelah itu, induk yang tertangkap dimasukkan ke dalam coolbox yang berisikan air laut. Induk yang tertangkap dipasangkan menjadi 9 pasang dengan perbandingan jantan betina 1 : 1 . Induk yang digunakan tidak luka, tidak cacat, dan berwarna seragam. Panjang total induk jantan 6-7 cm dan bobot berkisar 6-10 
gram sedangkan panjang induk betina 8-11 $\mathrm{cm}$ dan bobot 14-27 gram. Sebelum diberi perlakuan hormon, induk diaklimatisasi terlebih dahulu selama 7 hari. Selama aklimatisasi induk dipelihara langsung dalam wadah akuarium dan dilengkapi dengan anemon serta diberi pakan berupa potongan ikan rucah segar sampai induk respons terhadap pelet yang diberikan dengan frekuensi pemberian pakan dua kali sehari.

\section{Pembuatan pakan dan pemeliharaan}

Dosis hormon Oodev dalam penelitian ini sebesar $0 \mathrm{~mL} / \mathrm{kg}, 0,5 \mathrm{~mL} / \mathrm{kg}$, dan $1 \mathrm{~mL} / \mathrm{kg}$ dengan tiga ulangan diberikan secara oral melalui pakan. Pakan yang digunakan menggunakan pakan Otohime S2 dengan kadar protein $52 \%$. Hormon Oodev dicoating menggunakan putih telur ayam sebagai binder dan dimasukkan ke dalam botol spayer kemudian disemprot ke pakan hingga rata dan dikeringanginkan selama 30 menit.

Induk ikan giru dipelihara selama 30 hari dan diberikan makan secara restricted berdasarkan feeding rate 3\%. Frekuensi pemberian pakan sebanyak 2 kali sehari pada pagi dan sore. Selama pemeliharaan dilakukan pergantian air dan pengukuran kualitas air setiap minggu. Pengukuran kualitas air; salinitas (35-37 ppt), suhu (27$\left.30{ }^{\circ} \mathrm{C}\right), \mathrm{pH}(8,5-9)$, nitrit $(0,3-3 \mathrm{mg} / \mathrm{L})$, nitrat $(100 \mathrm{mg} / \mathrm{L})$ dan amoniak $(0,25 \mathrm{mg} / \mathrm{L})$.

\section{Parameter uji}

Parameter yang diuji dalam penelitian ini adalah pertumbuhan panjang dan bobot tubuh, masing-masing dengan menggunakan persamaan L dan W (Effendie 1997). Nilai Gonadosomatic Index (GSI) dihitung dengan menggunakan persamaan Ohta et al. (1996).

$$
L=L_{t}-L_{0}
$$

Keterangan:

$L=$ Pertumbuhan panjang tubuh $(\mathrm{cm})$

$L_{t}=$ Panjang ikan akhir pemeliharaan $(\mathrm{cm})$

$L_{o}=$ Panjang ikan awal pemeliharaan $(\mathrm{cm})$

$$
W=W_{t}-W_{0}
$$

Keterangan :

$W=$ Pertumbuhan bobot tubuh (gram)

$W_{t}=$ Bobot ikan akhir pemeliharaan (gram)

$W_{o}^{t}=$ Bobot ikan awal pemeliharaan (gram)

$$
G S I=\frac{B_{g}}{B_{t}} \times 100
$$

Keterangan :

GSI = Gonadosomatic Index (\%)

$B_{g} \quad=$ Bobot gonad (gram)

$B_{t}^{g} \quad=$ Bobot tubuh (gram)

\section{Analisis data}

Data hasil penelitian ditabulasi dan disajikan dalam bentuk histogram. Data dibahas secara deskriptif dan dibandingkan dengan sumber-sumber yang relevan. Tabulasi data menggunakan aplikasi Microsoft Excel 2010.

\section{HASIL DAN PEMBAHASAN}

Hasil pengukuran pertumbuhan yang berupa parameter panjang tubuh dan bobot tubuh disajikan pada Gambar 1 dan 2. Hasil menunjukkan bahwa pertumbuhan ikan giru baik panjang maupun bobot tubuh sejalan dengan dosis hormon Oodev yang diberikan. Dapat dilihat bahwa baik jantan dan betina mengalami pertumbuhan dalam hal panjang dan bobot tubuh pada akhir masa pemeliharaan.

Hasil penelitian menunjukkan bahwa pemberian hormon Oodev pada pakan dapat meningkatkan pertumbuhan dari ikan giru yang diberi perlakuan. Diketahui bahwa Oodev merupakan produk hormon yang mengandung hormon GnRH dan antidopanim yang sering digunakan untuk pematangan gonad tahap awal pada ikan (Hoga et al. 2018). GnRH merupakan neurohormon yang berperan dalam proses stimulus dan sintesis gonadotropin. Pada vertebrata termasuk ikan, peningkatan serum gonadotropin dalam darah memberikan feedback positif terhadap sekresi Leptin dan Neuropeptida Y (NPY) yang diketahui berpengaruh dalam regulasi pertumbuhan somatik (Cortes 2012; Hoga et al. 2018). Dalam penelitian ini tidak dilakukan pengukuran serum Leptin maupun NPY namun mekanisme kedua hormon ini dapat menjelaskan pertumbuhan yang terjadi pada ikan giru yang diberi perlakuan hormon Oodev. Semakin meningkatnya pertumbuhan bobot tubuh induk ikan giru membuktikan bahwa respons ikan terhadap pakan yang diberikan sangat baik pada setiap pemberian pakan. Dari hasil pengamatan selama masa pemeliharaan 30 
hari nafsu makan induk mulai meningkat pada pemeliharaan hari ke-14. Dari hasil pertumbuhan panjang dan bobot tubuh ikan giru dapat dilihat bahwa hormon Oodev memberi pengaruh positif lebih tinggi dari kontrol. Dapat dilihat juga bahwa perlakuan hormon Oodev dosis $1 \mathrm{~mL} / \mathrm{kg}$ memberi hasil terbaik dari dosis $0 \mathrm{~mL} / \mathrm{kg}$ dan $0,5 \mathrm{~mL} / \mathrm{kg}$. Hasil penelitian ini sejalan dengan Manik (2016) melakukan pemberian hormon Oodev dengan dosis $1 \mathrm{~mL} / \mathrm{kg}$ induk/minggu mempercepat pematangan gonad dan meningkatkan frekuensi pemijahan secara alami pada A. percula selama lima minggu.

Dalam penelitian ini, pemberian hormon Oodev pada pakan meningkatkan nilai GSI. Peningkatan nilai GSI sejalan dengan dosis yang diberikan. Pada Gambar 3 dapat dilihat bahwa nilai GSI tertinggi diperoleh pada kelompok perlakuan ke-3 (1 mL/kg). Telah diuraikan bahwa hormon Oodev mengandung hormon GnRH yang berperan dalam stimulus dan sekresi hormon gonadotropin. Hormon Oodev juga mengandung antidopamin yang memberikan efek positif terhadap sekresi gonadotropin (Hoga et al. 2018). Secara morfologi kematangan gonad dapat dilihat melalui penambahan bobot gonad akibat adanya perkembangan sel-sel gamet yang ada di dalam gonad (Cortes 2012). Perkembangan gonad baik pada jantan dan betina sejalan dengan pertambahan bobot tubuh yang diperoleh pada hari ke-30.

Nilai GSI diukur berdasarkan perbandingan bobot gonad dengan bobot tubuh somatik dalam persen. Pengukuran GSI digunakan untuk dapat menentukan stadia kematangan gonad dengan melihat hubungan pertumbuhan somatik dan perkembangan gonadnya (Wootton $\&$ Smith 2014). Hasil penelitian ini menunjukkan bahwa GSI jantan maupun betina masih dalam stadia perkembangan awal.

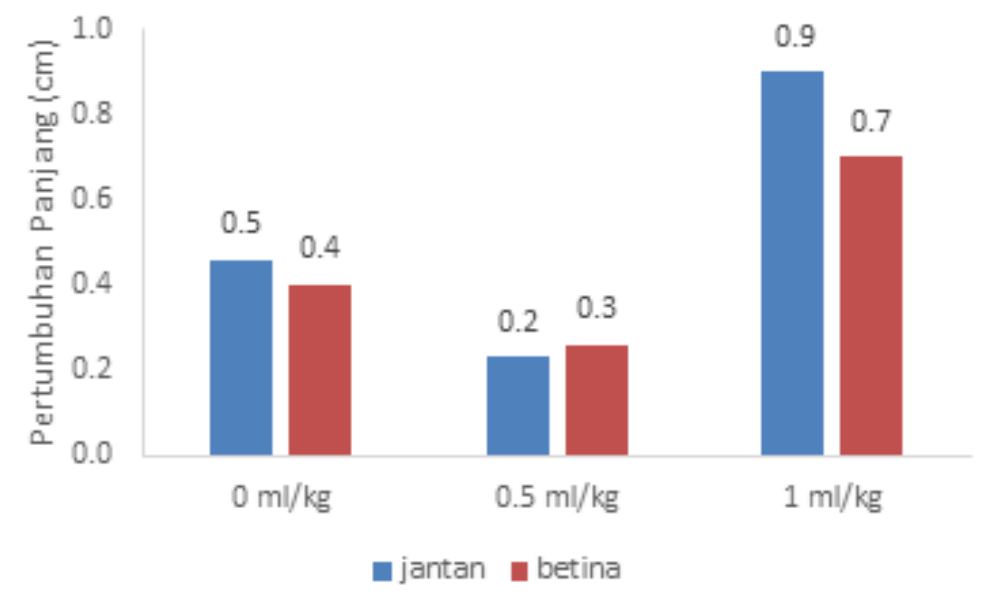

Gambar 1. Pertumbuhan panjang tubuh ikan giru (Amphiprion clarkii) yang diberi pakan mengandung Oodev dosis berbeda

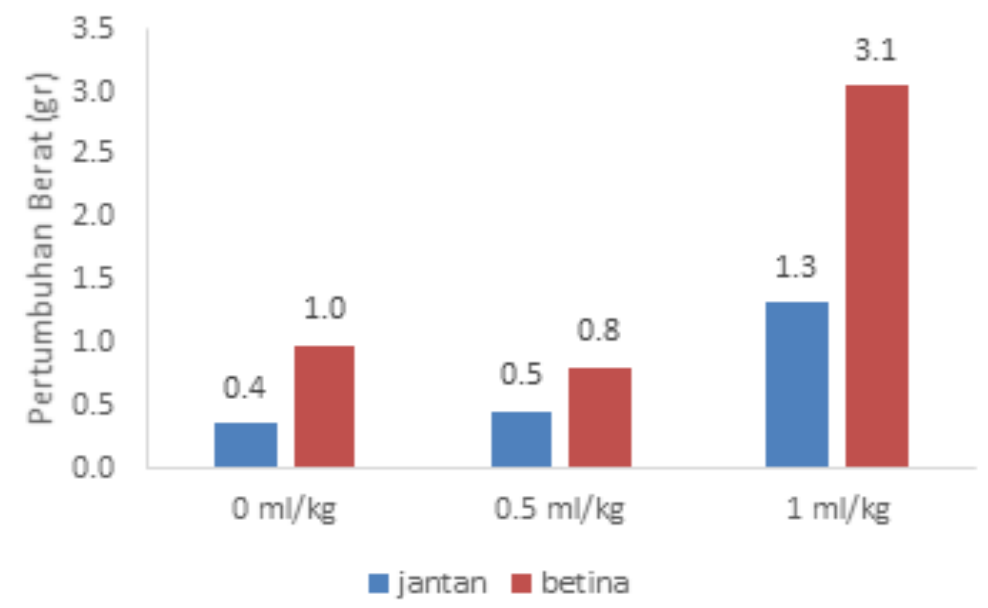

Gambar 2. Pertumbuhan bobot tubuh ikan giru (Amphiprion clarkii) yang diberi pakan mengandung Oodev dosis berbeda 


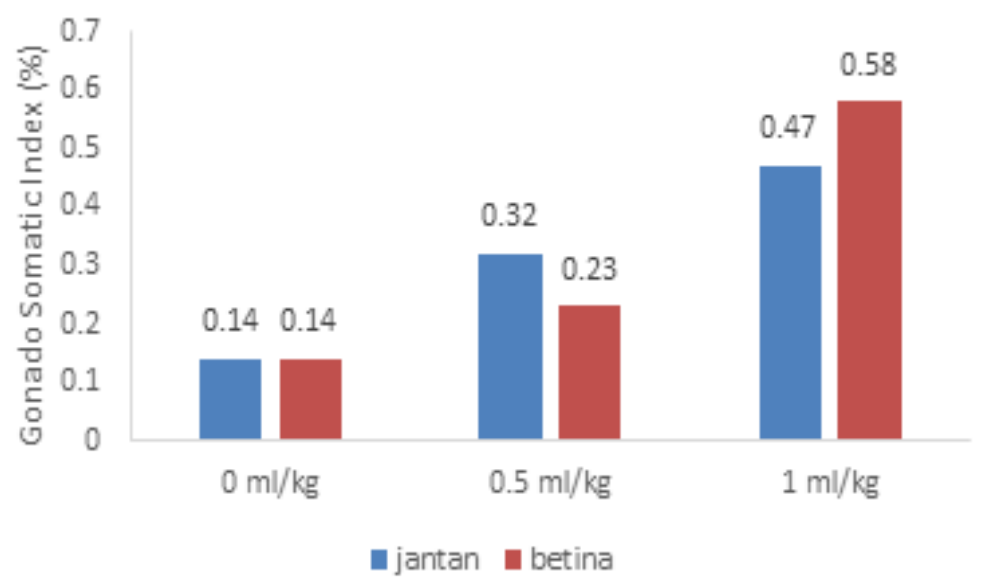

Gambar 3. Nilai GSI ikan giru pada hari ke-30

\section{KESIMPULAN DAN SARAN}

\section{Kesimpulan}

Berdasarkan hasil penelitian yang dilakukan selama 30 hari, dapat disimpulkan bahwa pemberian hormon Oodev dalam pakan dapat meningkatkan pertumbuhan baik pada jantan dan betina serta memicu pematangan gonad ikan giru yang dapat dilihat melalui nilai GSI yang diperoleh. Dosis terbaik pemberian hormon Oodev pada ikan giru adalah $1 \mathrm{~mL} / \mathrm{kg}$.

\section{Saran}

Penelitian lebih lanjut perlu dilakukan penambahan waktu selama aklimatisasi dan pemeliharaan, mengingat induk ikan giru yang digunakan dalam penelitian ini merupakan induk wild dari alam sehingga pengaruh yang diberikan oleh hormon Oodev dapat memperoleh hasil yang lebih baik.

\section{DAFTAR PUSTAKA}

[KKP]. 2017. KKP Lakukan Restocking Ribuan Ikan Nemo dan Kuda Laut di Perairan Pulau Tegal Lampung. http:/ / kkp.go.id/djpb/artikel/344kkp-lakukan-restocking-ribuanikan-nemo-dan-kuda-1aut-diperairan-pulau-tegal-lampung. April 2018].

Chen C, Fernald D. 2008. GnRH and GnRH Receptors: Distribution, Function, and Evolution. Journal of Fish Biology. 73 : 1099-1120.
Cortes ZTR. 2012. Gonadal Sex Steroid: Production, Action, and Interaction in Mammals. Intech, Chapter 1 : 1-42.

Effendie MI. 1997. Biologi Perairan. Yogyakarta: Yayasan Pustaka Nusantara.

Farida, Gunarsa S, Hasan H. 2018. Penambahan Tepung Kunyit dan Oodev dalam Pakan untuk Menginduksi Pematangan Gonad Induk Ikan Biawan (Helostoma temminkii). Jurnal Ruaya. 6 : 70-80.

Hoga CA, Almeida FL, Reyes FGR. 2018. A Review on the Use of Hormones in Fish Farming: Analytical Methods to Determine Their Residues. CyTAJournal of Food. 16 : 679-691.

Hutagalung RA, Widodo MS, Faqih AR. 2015. Evaluasi Aplikasi Hormon PMSG (Oodev $\left.{ }^{\circledR}\right)$ terhadap Indeks Hepatosomatik dan Gonadosomatik Ikan Gabus. Jurnal Akuakultur Indonesia. 14 : 24-29.

Manik L. 2016. Induksi pematangan gonad ikan badut (Amphiprion percula) menggunakan hormon oodev melalui pakan [Skripsi]. Bogor: Institut Pertanian Bogor.

Nur B, Cindelaras S, Meilisza N. 2017. Induksi Pematangan Gonad Ikan Gurami Coklat (Sphaerichthys osphromenoides Canestrini, 1860) menggunakan Pregnant Mare Serum Gonadotropin dan Antidopamin. Jurnal Riset Akuakultur. 12 : 69-76.

Ohta H, Kagawa H, Tanaka H, Okuzawa K, Hirose K. 1996. Changes in Fertilization and Hatching Rate with Time after Ovulation Induced by 17 , 20ß-dihydroxy-4-prenen-3-one in 
the Japanese eel, Anguilla Japonica. Aquaculture. 139 : 291-301.

Pirarat N, Pratakpiriya W, Jongnimitpaiboon K, Sajjawiriyakul K, Rodkhum C, Chansue N. 2011. Lymphocytis Disease in Cultured False Clown Anemonefish (Amphiprion ocellaris). Aquaculture. 315 : 414-416.

Pitaloka AD. 2007. Marjin Pemasaran pada Pemasokan Clownfish di CV Dinar Cabang Tangerang, Kabupaten Tangerang, Provinsi Banten [Skripsi]. Bogor: Institut Pertanian Bogor.

Rondonuwu AB, Tombokan JL, Rembet. 2013. Distribusi dan Kelimpahan Ikan Karang Famili Pomacentridae di Perairan Terumbu Karang Desa Poopoh Kecamatan Tombariri Kabupaten Minahasa. Jurnal Ilmiah Platax. 1 : 87-92.

Rousseau K, Aroua S, Schmitz M, Elie P, Dufour S. 2009. Silvering: Metamorphosis or Puberty? In: Van den Thillart, Dufour S, Rankin JC (eds). Spawning Migration of the European Eel. Berlin: Springer Science.

Sembiring S, Setiawati K, Hutapea J, Subamia W. 2013. Pewarisan Pola Warna Ikan Klon Biak, Amphiprion percula. Jurnal Ilmu dan Teknologi Kelautan Tropis. 5 : 343-351.

Tomasoa AM, Sudrajat AO, Junior MZ. 2015. Induksi Pematangan Gonad Ikan Sidat Menggunakan PMSG, Antidopamin dan Estradiol-17ß. Jurnal Akuakultur Indonesia. 14 : 112-121.

Wahyuningsih H. 2012. Induksi Buatan pada Perkembangan Gonad Ikan Tor Soro [Disertasi]. Bogor: Institut Pertanian Bogor.

Wootton RJ, Smith C. 2014. Gametogenesis. In: Wootton, R.J., Smith, C. (Eds.), Reproductive Biology of Teleost Fishes. 